\title{
Glycemic index and load responses of indigenous vegetable sauces among healthy young female adults
}

\author{
*Joy Amadi A.C ${ }^{1}$, Asinobi, C.O ${ }^{1}$, Okechukwu-Ezike, N.C ${ }^{2}$, Aloy-Amadi, $O^{3}$. and \\ Ihemeje, $\mathbf{A}^{2}$
}

${ }^{1}$ Department of Nutrition and Dietetics, Imo State University P.M.B. 2000, Owerri, Nigeria; ${ }^{2}$ Department of Food Science and Technology, Imo State University P.M.B. 2000, Owerri, Nigeria; ${ }^{3}$ Department of Medical Laboratory Science, Imo State University P.M.B. 2000, Owerri, Nigeria

Corresponding author: Joy Amadi, PhD, Department of Nutrition and Dietetics, Imo State University P.M.B. 2000, Owerri, Nigeria

Submission Date: May 29 ${ }^{\text {th }}$ 2019. Acceptance Date: September $27^{\text {th }}$, 2019. Publication Date: September $30^{\text {th }}, 2019$.

Citation: Joy Amadi A.C, Asinobi C.O., Okechukwu-Ezike, N.C., Aloy-Amadi O. and Ihemeje A. Glycemic index and load responses of indigenous vegetable sauces among healthy young female adults. Functional Foods in Health and Disease 2019; 9(9): 576-592. DOI: https://doi.org/10.31989/ffhd.v9i9.621

\begin{abstract}
Background: Low glycemic index, load, and response food has been implicated in reducing the incidence of Type 2 Diabetes Mellitus (T2DM). Also, the use of locally made foods has been advocated for in the management of diabetes mellitus in recent times. The aim of this study is to investigate glycemic and load response of non-diabetic females with a diet consistent of various indigenous vegetables.
\end{abstract}

Methods: The recipe for the test food was developed and standardized. Proximate and dietary fiber analysis was carried out on the test food (okra, African spinach, and lettuce sauces) and reference food (white bread). Thirty-six non-diabetic undergraduate students of Imo State University, Nigeria were selected after diabetes screening using oral glucose tolerance test (OGTT), glycated hemoglobin, anthropometric indices, blood pressure, and other exclusion criteria. Subjects consumed a serving portion of vegetable sauce containing $25 \mathrm{~g}$ of digestible carbohydrate. Postprandial plasma glucose was measured at 0, 15, 30, 45, 60, 90, and 120 minutes. The glycemic index and load were calculated per serving. Means and standard deviations were used to compute the average. Analysis of variance (ANOVA) was used to compare the means while Tukey's test was used to separate the means. Significant difference and decision criterion were set at $\mathrm{p}<0.05$ using Statistical Package for the Social Sciences (SPSS) version 22.0. 
Results: Moisture content ranged from $64.10 \pm 0.57 \%$ (okra sauce) to $64.62 \pm 0.66 \%$ (lettuce sauce) did not differ significantly $(\mathrm{p}<0.05)$. Fat, fiber, and ash content higher in lettuce sauce $3.40 \pm$ $0.24 \%, 1.69 \pm 0.1 \% 2$, and $4.40 \pm 0.24 \%$ respectively, carbohydrate was higher in African spinach $(15.07 \pm 0.77 \%)$ while dietary fiber $(3.26 \pm 0.01 \%)$, protein $(15.15 \pm 0.09 \%)$ and energy $(136.62 \pm 2.24$ kcal) was higher in okra sauce. Sauces were not significantly different. White bread shows that moisture content was 17.62 , fat $1.53 \%$, protein $14.86 \%$, ash $6.90 \%$, carbohydrate $58.88 \%$, energy $308.66 \mathrm{kcal}$, and dietary fiber 0.33 .The anthropometric indices show that body mass index (BMI) of the subjects ranged from $23.12 \mathrm{~kg} / \mathrm{m}^{2}$ in African spinach sauce subjects to $23.53 \mathrm{~kg} / \mathrm{m}^{2}$ (okra sauce subjects). Waist hip ratio (WHR) was highest in lettuce sauce subjects (0.84). All the subjects that participated were all females. HbA1 $\mathrm{C}$ was higher in okra sauce $(5.23 \%)$ group subjects. Systolic blood pressure was $119.08 \mathrm{mmHg}$ (African Spinach sauce subjects) while diastolic blood pressure was highest in lettuce sauce subjects $(85.68 \mathrm{mmHg})$. Pulse rate (85.17) was highest in okra sauce subjects. The incremental area under curve (IAUC) for the white bread was significantly $(\mathrm{p}<0.05)$ higher in all the subjects compared to the vegetable sauces with a high glycemic index and load of 93.25 and 54.91 respectively. African spinach sauce had a lower postprandial plasma glucose peak of $88.00 \mathrm{mg} / \mathrm{dl}$ at 60 minutes compared to okra and lettuce sauces. All the vegetable sauces had a low glycemic index of 17.02 (okra sauce), 14.05 (African spinach) and 36.76 (lettuce), and low glycemic load was $0.75,0.38$ and 3.80 for okra, African spinach, and lettuce sauces, respectively.

Conclusion: All the vegetable sauces studied should be recommended while planning meals for diabetic patients.

Keywords: vegetable sauces, glycemic response, healthy female adults

\section{INTRODUCTION}

Vegetables include those leafy and/or root parts of plants that are used in making soup or sauce or eaten with another food [1]. Green leafy vegetables are important in human nutrition as they provide adequate amounts of vitamins and minerals. They are rich source of micronutrients like beta-carotene, vitamin $\mathrm{C}$, riboflavin, folic acid, calcium, iron, and phosphorous [2]. They are regarded as protective foods and highly beneficial for the maintenance of good health and prevention of diseases [3]. The bioactive or phytochemicals in fruits and vegetables are responsible for this protective effect [4]. Over two decades, epidemiological studies have shown a diminished risk of diet-related chronic diseases among people consuming diets high in fruits and vegetables [5].

Phytochemicals in vegetables also exert both antioxidants and anti-inflammatory properties [6]. Antioxidants dispose oxygen species and free radicals by scavenging and suppressing their formation or opposing their actions. Prevention of free radical formation helps in preventing oxidative stress and diabetic complications. Antioxidants may act at different levels, inhibiting the formation of reactive oxygen species (ROS) or scavenge free radicals, or increase the antioxidants defense enzyme capabilities. Antioxidants from foods include vitamins A, C, and E and carotenoids may increase plasma antioxidant level. When the body is unable to remove reactive molecules, it leads to inflammation, tissue damage, and diabetes complications in subjects. Increasing incidence of type 2 diabetes mellitus is one of the global health challenges and becoming a major public health problem in Nigeria [2]. Type 2 diabetes mellitus is a consequence 
of carbohydrate, protein, and lipid metabolism caused by lack of/reduced insulin production (Type IDM) or resistance to insulin action (Type 2DM) [7]. The causes are linked to poor dietary habits, lack of nutritional knowledge of foods, poverty, globalization, and adoption of western dietary patterns and lack of physical exercise [8].

Glycemic index (GI) of a food is the increase above the fasting in the blood glucose area over $2 \mathrm{~h}$ after ingestion of a constant amount of that food (usually a $50 \mathrm{~g}$ carbohydrate portion) divided by the response to a reference food (usually glucose or white bread). Low glycemic index foods improve lipid profile, reduce C-reactive protein levels, reduce weight gain, promote increased levels of high-density lipoprotein cholesterol, and reduce the risk of type 2 diabetes mellitus (T2DM) and cardiovascular diseases [9]. The glycemic load (GL) of a particular food portion size indicates the impact the food will have in affecting blood glucose level. GL considers the amount of carbohydrate a serving of food contains.

Sauces can be defined as meals prepared by boiling solid ingredients in liquid until the flavor is extracted which forms a broth that is not as thick as soup [10]. Sauces are mostly taken alongside with fufu, yam, pasta, or rice. In recent times, the use of locally made foods has been advocated for the management of diabetes mellitus. This is because the use of synthetic drugs has adverse effects on people with chronic complications. Recent study has revealed that Abelmoscus esculentus (okra), Amaranthus hybridus (African spinach), and Lactuca sativa (lettuce) have antidiabetic properties [11].

There is a paucity of studies on the glycemic index and load response of okra, African spinach, and lettuce sauces. Therefore, this work sought to determine the glycemic index and load response of these vegetable sauces on healthy young adults.

\section{MATERIALS AND METHODS}

\section{Sample Procurement}

The okra pods, lettuce, African spinach, and other ingredients for cooking and medical materials were purchased from Relief market along Egbu road Owerri Municipal Local Government Area of Imo State, Nigeria.

\section{Recipe for different vegetable sauces Ingredients}

$300 \mathrm{~g}$ of each of the vegetables (okra, African Spinach, and lettuce), 200g of sliced onions, $45 \mathrm{~g}$ of palm oil, $150 \mathrm{~g}$ of milled crayfish, $8 \mathrm{~g}$ of wet Milled pepper, $3 \mathrm{~g}$ of salt, $200 \mathrm{~g}$ of sliced tomatoes, and $200 \mathrm{~g}$ (okra) and 50g (African spinach and lettuce, respectively) of water.

\section{Method of preparation}

The fresh okra pods were sorted, washed in clean water, and sliced into small sizes (in the same consistency so that the chewing time will be controlled and in a way in a way that digestion will take place immediately). Other vegetables like onions and tomatoes were sliced. The pot was washed and placed on a fire and allowed to dry. The palm oil was added and allowed to heat for 5 seconds; the onions were then added. The palm oil was not allowed to heat up before adding the onion so as to avoid hydrogenation). The tomatoes were added and allowed to steam for 9 minutes. Crayfish, pepper, and salt were added and allowed to steam for 3 minutes. Okra was added and allowed to simmer for 5 minutes. It was brought down and served. The same procedure was 
employed in preparing lettuce and African Spinach sauces except that the lettuce was allowed to simmer for 2 minutes.

\section{Data collection and analysis}

\section{Sensory Evaluation}

Sensory evaluation of vegetable sauces was carried out with 50 trained judges consisting of students of the Nutrition and Dietetics Department at Imo State University, Nigeria. The sensory evaluation was carried out in the Food Laboratory of the Nutrition and Dietetics Department, Faculty of Health Sciences, Imo State University. Aroma, color, taste, texture, and overall acceptability were rated on a 9-point hedonic scale, ranging from 1 (like extremely) to 9 (dislike extremely) [12]. Judges were given glass of portable water to rinse their mouth after each tasting.

\section{Proximate, dietary and energy value estimation}

The cooked sauces were analyzed for proximate, dietary fiber, and energy value was calculated using standard methods. Standard AOAC method [13] was employed for the determination of protein, moisture, fat, ash, and crude fiber content of the vegetable sauces. Carbohydrate content was determined by difference. Dietary fiber was determined as described by McCleay et al. [14]. Energy value was determined using Atwater factor [15].

\section{Survey Design}

A cross-sectional study design was used for the study.

\section{Sampling technique}

Thirty-six healthy non-diabetic female students out of 100 male and female students of Nutrition and Dietetics Department, Imo State University who volunteered were selected after a brief explanation of the study and request for indication of interest as well as diabetic screening, along with health related questionnaire to identify and exclude smokers and alcoholics. The diabetic screening of the students as well as the oral glucose tolerance test were carried out in the Nutrition and Dietetic food laboratory by 7:30am. They were asked to fast, and after resting for 30 minutes, a capillary pricked finger blood sample was taken as baseline and the fasting blood sugar was determined using calibrated Accu-check glucometer which gave a direct reading after 5 seconds for the oral glucose tolerance test (OGTT). Subjects were served with glucose solution containing $75 \mathrm{~g}$ glucose dissolved in $250 \mathrm{ml}$ of water, which was consumed within 15 minutes. Blood glucose was determined after 2 hours of glucose solution consumption. Simple random sampling was used in selecting thirty-six students whose blood glucose was $<7.8 \mathrm{mmol} / 1(<140 \mathrm{mg} / \mathrm{dl})$. They were asked to come back for glycated hemoglobin determination after 3 days. The 36 selected students who met the inclusion criteria were classified into three vegetable sauce groups. Out of the 36 students, 12 students were randomly selected for each of the three vegetables sauces: okra, lettuce, and African spinach.

\section{Inclusion and Exclusion criteria}

The "inclusion criteria" were signed written informed consent and subjects who do not fall into any of the exclusion criteria while "exclusion criteria" for the study generally involves diabetic 
young adults, subjects with impaired glucose tolerance, smokers, alcoholics, strenuous exercise, pregnant mothers, and consumption of a meal after dinner.

\section{Ethical consideration}

Informed written consent was obtained from the randomly selected students. Also, written approval for the study was obtained from the committee for ethical consideration, College of Medicine Imo State University.

\section{Recruiting and training of research assistance}

Three medical laboratory scientists were recruited from Federal Medical Center (FMC) Owerri, Nigeria for blood collection, determination of blood glucose and glycated hemoglobin. Ten final year undergraduate students of the Department of Nutrition and Dietetics, Faculty of Health Sciences were recruited as research assistants. The objectives and techniques of the study were explained to them.

\section{Anthropometric measurements}

Data on weight, height, waist, and hip measurements were taken from the selected samples and classified according to WHO [16] criteria. BMI was classified as underweight ( $<18.5)$, normal (18.5-24.9), overweight (25.0-29.9), and obese ( $\geq 30.0)$. Waist-hip ratio (WHR) was classified as $<0.9$ as no risk, moderate risk (0.9-1), and high risk ( $>1.0)$ for males; and $\leq 0.8$ as no risk, 0.81 to 0.84 as moderate risk, and $>0.85$ as high risk for females.

\section{Biochemical measurements}

Determination of blood glucose using oxidize method was carried out according to the method described by Williams et al. [17]. Normal blood glucose level was used as 75 to $115 \mathrm{mg} / \mathrm{dl}$. Glycated hemoglobin $\left(\mathrm{HbA} 1_{c}\right)$ was estimated using Finecare $\mathrm{HbA} 1_{c}$ rapid quantitative test kit that uses sandwich immune-detection method to measure the percentage of $\mathrm{HbA} 1_{\mathrm{c}}$ in human blood. Classification for $\mathrm{HbA} 1_{c}$ was 4\%-5.6\% (normal), 5.7\%-6.4\% (pre-diabetes), and $\geq 6.5 \%$ (diabetic). Blood pressure and pulse rate were determined using Omiron apparatus model HEM-721C and classified as described by the WHO/ISH [18]. Hypertension was classified as a systolic and diastolic blood pressure of $140 \mathrm{mmhg}$ and $90 \mathrm{mmHg}$, respectively, or above, while pulse rate was 60-100 beats per minute.

\section{Feeding procedure}

The procedure used follows Bronus et al.'s procedure [19] which agrees with the procedure approved by FAO/WHO [20] for glycemic index studies following overnight fasting of 10 hours. Subjects arrived at the study site by 7:30am for glycemic response determination of the reference food and were advised to rest for 30 minutes. Blood was collected for fasting blood sugar after an overnight fast of 10 to 14 hours and was recorded as the 0 -minute mark. They were served $25 \mathrm{~g}$ digestible carbohydrate of white bread with $250 \mathrm{ml}$ of water which was consumed within 15 minutes at 5 minute intervals for each subject (to enable adequate time for accurate data collection). Venous blood ( $3 \mathrm{mls}$ ) was collected exactly after 15 minutes following the first bite of bread and at 30, 45, 60, 90, and 120 minutes. The same method was applied for the test foods after a washout period of 2 days. On the second day, each vegetable sauce was fed with $25 \mathrm{~g}$ of digestible 
carbohydrate of okra, lettuce, and African spinach sauce (test foods) with $250 \mathrm{ml}$ of water and consumed within 15 minutes. Venous blood was collected from the subjects exactly after 15 minutes after the first bite of bread and at 30, 45, 60, 90, and 120 minutes. The subjects were asked to remain seated to avoid physical activity during the metabolic study until after 2 hours. Incentives (doughnuts, fresh milk, fresh tomatoes, eggs, zobo juice, and water) were given to the volunteers after each experiment day.

\section{Glycemic Index determination}

The G.I (glycemic index) for the test foods for all the subjects was calculated as:



Where:

IAUC $=$ Incremental Area Under the blood response curve for the test meal.

IAUCS = Incremental Area under the blood response curve for the standard reference meal.

Data collected on Glycemic index were coded; means, standard deviations, and percentages were calculated and tabulated.

Glycemic Index classification according to Kati et al. [21] was used as $70 \%$ to $100 \%=$ high glycemic index, $56 \%$ to $69 \%=$ medium glycemic index, and $\leq 55 \%=$ low glycemic index .

\section{Glycemic Load (GL) determination}

According to Das et al. [23], GL is calculated as:

G.L food $=\underline{\text { G.I food } \times \text { amount }(\mathrm{g}) \text { of available carbohydrate food per serving }}$

100

Glycemic Load was graded according to Brand-Miller et al. [22] as $\geq 20 \%$ or above $=$ high, $11 \%$ - $19 \%=$ medium, and $\leq 10 \%=$ low .

\section{Glycemic Response (GR)}

Glycemic response (GR) of the test foods was calculated based on the time with which the test food had effect on blood glucose after consumption. Data collected on the time and blood glucose levels rises were coded and means were calculated. The literature does not have criteria for classifying Glycemic response (GR).

\section{Statistical analysis}

Data were analyzed using Statistical Package for the Social Sciences (SPSS) version 21 for means and standard deviation. Means and standard deviation was used to compute the average. Analysis of variance (ANOVA) was used to compare the means while Tukey's test was used to separate the means. Significant difference was set at $\mathrm{p}<0.05$.

\section{RESULTS}

\section{Proximate, dietary fiber and energy composition of vegetable sauces}

Table 1 shows the proximate, dietary fiber and energy composition of the vegetable sauces. Moisture content of the sauces did not differ significantly $(\mathrm{p}<0.05)$. Fat, fiber, and ash content was higher in lettuce sauce $3.40 \pm 0.24 \%, 1.69 \pm 0.12 \%$, and $4.40 \pm 0.24 \%$, respectively; carbohydrates 
were higher in African spinach $(15.07 \pm 0.77 \%)$, while dietary fiber $(3.26 \pm 0.01 \%)$, protein $(15.15 \pm 0.09 \%)$, and energy $(136.62 \pm 2.24 \%)$ were higher in okra sauce. Sauces were not significantly different $(\mathrm{p}<0.05)$.

Table 1: Proximate, dietary fiber and energy composition of vegetable sauces.

\begin{tabular}{llcc}
\hline Nutrient & Okra sauce & $\begin{array}{c}\text { African Spinach } \\
\text { Sauce }\end{array}$ & Lettuce sauce \\
\hline Moisture $(\%)$ & $64.10^{\mathrm{a}} \pm 0.57$ & $64.44^{\mathrm{a}} \pm 0.65$ & $64.62^{\mathrm{a}} \pm 0.66$ \\
Fat $(\%)$ & $1.82^{\mathrm{a}} \pm 0.13$ & $1.21^{\mathrm{b}} \pm 0.06$ & $3.40^{\mathrm{a}} \pm 0.24$ \\
Protein $(\%)$ & $15.15^{\mathrm{a}} \pm 0.09$ & $14.75^{\mathrm{a}} \pm 0.10$ & $13.74^{\mathrm{a}} \pm 0.16$ \\
Crude fibre $(\%)$ & $1.20^{\mathrm{a}} \pm 0.03$ & $1.31^{\mathrm{a}} \pm 0.09$ & $1.69^{\mathrm{a}} \pm 0.12$ \\
Ash $(\%)$ & $2.82^{\mathrm{a}} \pm 0.14$ & $3.22^{\mathrm{a}} \pm 0.58$ & $4.40^{\mathrm{a}} \pm 0.24$ \\
Carbohydrate $(\%)$ & $14.91^{\mathrm{a}} \pm 0.76$ & $15.07^{\mathrm{a}} \pm 0.77$ & $12.15^{\mathrm{b}} \pm 0.02$ \\
Energy (kcal) & $136.62^{\mathrm{a}} \pm 2.24$ & $130.17^{\mathrm{a}} \pm 2.99$ & $134.10^{\mathrm{a}} \pm 4.03$ \\
Dietary fiber $(\mathrm{g})$ & $3.26^{\mathrm{a}} \pm 0.01$ & $2.39^{\mathrm{a}} \pm 0.14$ & $2.25^{\mathrm{a}} \pm 0.02$ \\
\hline
\end{tabular}

Values are means \pm SD (Standard deviation) of triplicate determination. Mean values of different superscript $(a, b, c)$ in the same row are significant at $\mathrm{p}<0.05$.

\section{Sensory evaluation of the vegetable sauce}

The sensory evaluation of the vegetables sauces shows that color, taste, and texture sensory parameters did not differ between okra and lettuce sauces but were significantly $(\mathrm{p}<0.05)$ different from African spinach. Okra sauce was significantly higher in aroma (8.27 \pm 1.0$)$ and general acceptability $(8.2 \pm 0.74)$ compared to the African spinach and lettuce sauces.

Table 2: Sensory evaluation of vegetable sauce.

\begin{tabular}{llcc}
\hline Parameters & Okra sauce & $\begin{array}{l}\text { African Spinach } \\
\text { sauce }\end{array}$ & Lettuce sauce \\
\hline Aroma & $8.27^{\mathrm{a}} \pm 1.0$ & $6.61^{\mathrm{c}} \pm 1.49$ & $7.43^{\mathrm{b}} \pm 1.24$ \\
Colour & $8.23^{\mathrm{a}} \pm 0.90$ & $6.45^{\mathrm{b}} \pm 1.92$ & $7.43^{\mathrm{a}} \pm 1.24$ \\
Taste & $8.29^{\mathrm{a}} \pm 0.90$ & $6.69^{\mathrm{b}} \pm 1.92$ & $7.71^{\mathrm{a}} \pm 0.98$ \\
Texture & $8.33^{\mathrm{a}} \pm 0.91$ & $6.69^{\mathrm{b}} \pm 1.22$ & $7.89^{\mathrm{a}} \pm 0.96$ \\
General & $8.29^{\mathrm{a}} \pm 0.74$ & $6.24^{\mathrm{c}} \pm 1.39$ & $7.76^{\mathrm{b}} \pm 1.23$ \\
acceptability & & & \\
\hline
\end{tabular}

Mean values of with different superscript $(a, b, c)$ in the same row are significant at $p<0.05$. $\mathrm{N}=50$

\section{Anthropometric and Health characteristics of the subjects}

The age of the subjects ranged from 22 to 24 years old. Anthropometric value shows that the BMI of the subjects ranged from $23.12 \mathrm{~kg} / \mathrm{m}^{2}$ in subjects that consumed the African spinach sauce to $23.53 \mathrm{~kg} / \mathrm{m}^{2}$ in subjects that the consumed okra sauce. Waist Hip Ratio (WHR) ranged from 0.78 in African spinach sauce subjects to 0.84 in lettuce sauce subjects, the values were within the recommended range for females. All the subjects that participated were females. Although the glycated hemoglobin $\left(\mathrm{HbA} 1_{\mathrm{C}}\right.$ ) was higher in those consumed okra sauce $(5.23 \%)$, all the subjects had normal $\mathrm{HbA} 1_{\mathrm{C}}$ values. The systolic pressure of all the subjects from the different vegetable sauces fell within the normal ranges but were not significantly $(\mathrm{p}<0.05)$ different. A similar 
observation was obtained for diastolic pressure except in those subjects that consumed lettuce sauces (Table 3). Although pulse rate was higher in okra sauce subjects, the differences were not significant $(\mathrm{p}<0.05)$.

Table 3: Anthropometric and Health characteristics of the subjects.

\begin{tabular}{|c|c|c|c|}
\hline Parameter & $\begin{array}{l}\text { Lettuce sauce } \\
(\mathrm{n}=12)\end{array}$ & $\begin{array}{l}\text { African spinach } \\
\text { sauce }(n=12)\end{array}$ & $\begin{array}{l}\text { Okra sauce } \\
(n=12)\end{array}$ \\
\hline Age (years) & $23.00^{\mathrm{a}} \pm 2.17$ & $24.00^{\mathrm{a}} \pm 2.22$ & $22.00^{\mathrm{a}} \pm 2.19$ \\
\hline Height (m) & $1.62^{\mathrm{a}} \pm 9.94$ & $1.69^{\mathrm{a}} \pm 8.45$ & $1.59^{\mathrm{a}} \pm 7.59$ \\
\hline Weight (kg) & $60.38^{\mathrm{a}} \pm 5.81$ & $66.67^{\mathrm{a}} \pm 11.09$ & $60.10^{\mathrm{a}} \pm 7.47$ \\
\hline \multicolumn{4}{|l|}{ BMI $\left(18.5-24.0 \mathrm{~kg} / \mathrm{m}^{2}\right)$} \\
\hline & $23.27^{\mathrm{a}} \pm 4.16$ & $23.12^{\mathrm{a}} \pm 0.26$ & $23.53^{\mathrm{a}} \pm 2.60$ \\
\hline Waist (cm) & $76.33^{\mathrm{a}} \pm 8.91$ & $70.50^{\mathrm{a}} \pm 8.68$ & $75.33^{\mathrm{a}} \pm 8.87$ \\
\hline Hip (cm) & $90.83^{\mathrm{a}} \pm 4.88$ & $89.41^{\mathrm{a}} \pm 3.26$ & $90.83^{\mathrm{a}} \pm 4.88$ \\
\hline WHR $(<0.9)$ & $0.84^{\mathrm{a}} \pm 0.57$ & $0.78^{\mathrm{a}} \pm 0.26$ & $0.83^{\mathrm{a}} \pm 0.79$ \\
\hline $\mathrm{HbA1}_{C}(4 \%-5.6 \%)$ & $5.14^{\mathrm{a}} \pm 0.42$ & $5.17^{\mathrm{a}} \pm 0.41$ & $5.23^{\mathrm{a}} \pm 0.34$ \\
\hline Systolic (120mmHg) & $104.58^{\mathrm{a}} \pm 0.42$ & $119.08^{\mathrm{a}} \pm 20.02$ & $111.83^{\mathrm{a}} \pm 9.24$ \\
\hline Diastolic (80mmHg) & $85.68^{\mathrm{a}} \pm 0.42$ & $72.58^{\mathrm{b}} \pm 9.39$ & $71.58^{\mathrm{b}} \pm 7.37$ \\
\hline $\begin{array}{l}\text { Pulse rate }(60-100 \\
\text { beats/minutes) }\end{array}$ & $83.08^{\mathrm{a}} \pm 11.77$ & $84.17^{\mathrm{a}} \pm 8.68$ & $85.17^{a} \pm 10.38$ \\
\hline
\end{tabular}

Mean values of with different superscript $(a, b, c)$ in the same row are significant at $p<0.05 . N=50$

Number of subjects for each vegetable sauce $=12$. Sex $=$ females.

Table 4: Total carbohydrates, digestible carbohydrates, portion size, and serving portion used for blood glucose estimation.

\begin{tabular}{|l|l|l|l|l|l|}
\hline \multirow{2}{*}{$\begin{array}{l}\text { Vegetable } \\
\text { sauce }\end{array}$} & \multirow{2}{*}{$\begin{array}{l}\text { Digestible } \\
\text { carbohydrate }(\mathbf{g})\end{array}$} & $\begin{array}{l}\text { Serving portions } \\
\text { (g) for 25g } \\
\text { digestible } \\
\text { carbohydrate }\end{array}$ & $\begin{array}{l}\text { Ratio of the } \\
\text { portion }\end{array}$ & $\begin{array}{l}\text { Nutrient in } \\
\text { expressed }\end{array}$ & $\begin{array}{l}\text { Serving } \\
\text { percentages }\end{array}$ \\
\cline { 4 - 6 } & & & $\begin{array}{l}\text { Carbohydrate } \\
(\mathbf{g})\end{array}$ & Protein (g) & Fat (g) \\
\hline $\begin{array}{l}\text { Okra sauce } \\
\text { nfrican } \\
\text { spinach } \\
\text { sauce }\end{array}$ & 11.65 & 214.59 & 31.91 & 32.51 & 3.91 \\
\hline $\begin{array}{l}\text { Lettuce } \\
\text { sauce }\end{array}$ & 12.68 & 197.16 & 29.08 & 29.08 & 2.39 \\
\hline
\end{tabular}

Lettuce sauce had the lowest digestible carbohydrates $(9.90 \mathrm{~g})$, ratio of carbohydrates, $(23.95 \mathrm{~g})$ and protein $(27.09 \mathrm{~g})$ in the serving portion; but the highest serving portion of digestible carbohydrates $(252.53 \mathrm{~g})$ and fat $(6.70 \mathrm{~g})$ (Table 4$)$. 
Average blood glucose response to vegetable sauces and white bread at intervals

The baseline plasma glucose was higher in subjects that consumed African spinach (78.25mg/dl) as compared to other sauces. The IUAC for the white bread was significantly $(\mathrm{p}<0.05)$ higher in all the subjects in all the vegetable sauces. There was a significant $(p<0.05)$ difference in the mean blood glucose of the subjects after the consumption of the different vegetable sauces over a period of 2 hours. Glycemic response to the vegetable sauces was highest in the lettuce sauce $(91.08 \mathrm{mg} / \mathrm{dl})$ at 45 minutes and highest in the African spinach sauce $(88.00 \mathrm{mg} / \mathrm{dl})$ at 60 minutes.

The average blood glucose response to the African spinach sauce was lower at 15 minutes $(79.33 \mathrm{mg} / \mathrm{dl}), 30$ minutes $(82.25 \mathrm{mg} / \mathrm{dl})$, and 45 minutes $(84.83 \mathrm{mg} / \mathrm{dl})$ compared to other vegetable sauces but gradually increased to its peak after 60 minutes $(88.00 \mathrm{mg} / \mathrm{dl})$. After 120 minutes, the postprandial glucose of the African spinach sauce decreased to its minimum of 73.92 $\mathrm{mg} / \mathrm{dl}$ (Table 5). Lettuce and okra sauce consumption gradually increased plasma concentration from 15 minutes though higher in lettuce sauce to a maximum peak of $91.08 \mathrm{mg} / \mathrm{dl}$ and 88.83 $\mathrm{mg} / \mathrm{dl}$ respectively at 45 minutes (Figure 1-4). The postprandial blood glucose increase and decrease of the vegetable sauce shows that the highest postprandial increase was in the lettuce sauce $(13.16 \mathrm{mg} / \mathrm{dl})$ at 15 minutes while the highest decrease was observed in African spinach sauce $(-7.83 \mathrm{mg} / \mathrm{dl})$ at 120 minutes (Table 6). From the study, the postprandial plasma glucose of the vegetable sauces had a low glycemic index of 17.02 (okra sauce), 14.05 (African spinach), and 36.76 (lettuce). The glycemic load was $0.75,0.38$ and 3.80 for okra, African spinach, and lettuce sauces, respectively (Table 7).

Table 5: Average blood glucose response to vegetable sauces at intervals (mg/dl).

\begin{tabular}{|c|c|c|c|c|c|c|c|}
\hline $\begin{array}{l}\text { Vegetable } \\
\text { sauces and } \\
\text { white bread }\end{array}$ & $\begin{array}{c}0 \\
\text { minute }\end{array}$ & 15 minutes & $\begin{array}{l}30 \\
\text { minutes }\end{array}$ & $\begin{array}{l}45 \\
\text { minutes }\end{array}$ & 60 minutes & $\begin{array}{l}90 \\
\text { minutes }\end{array}$ & $\begin{array}{l}120 \\
\text { minutes }\end{array}$ \\
\hline Okra sauce & $\begin{array}{l}77.33^{\mathrm{b}} \\
\pm 9.94\end{array}$ & $\begin{array}{l}87.33^{\mathrm{b}} \\
\pm 9.91\end{array}$ & $\begin{array}{l}86.50^{\mathrm{b}} \\
\pm 11.53\end{array}$ & $\begin{array}{l}88.83^{\mathrm{b}} \\
\pm 15.14\end{array}$ & $\begin{array}{l}85.00^{\mathrm{b}} \\
\pm 7.97\end{array}$ & $\begin{array}{l}81.75^{\mathrm{b}} \pm \\
7.97\end{array}$ & $\begin{array}{l}77.00 \\
\pm 8.16\end{array}$ \\
\hline $\begin{array}{c}\text { Reference } \\
\text { (control) }\end{array}$ & $\begin{array}{l}83.41^{\mathrm{a}} \\
\pm 5.21\end{array}$ & $\begin{array}{l}98.92^{\mathrm{a}} \pm \\
10.32\end{array}$ & $\begin{array}{l}82.25 \pm \\
11.89\end{array}$ & $\begin{array}{l}121.50^{\mathrm{a}} \pm \\
10.81\end{array}$ & $\begin{array}{l}113.67^{\mathrm{a}} \\
\pm 8.49\end{array}$ & $\begin{array}{l}109.25^{\mathrm{a}} \pm \\
9.81\end{array}$ & $\begin{array}{l}98.92 \pm \\
12.56\end{array}$ \\
\hline $\begin{array}{l}\text { African spinach } \\
\text { sauce }\end{array}$ & $\begin{array}{l}78.25^{\mathrm{b}} \pm \\
2.53\end{array}$ & $\begin{array}{l}79.33^{\mathrm{b}} \pm \\
12.33\end{array}$ & $\begin{array}{l}82.25^{\mathrm{b}} \pm \\
11.89\end{array}$ & $\begin{array}{l}84.83^{\mathrm{b}} \pm \\
12.22\end{array}$ & $\begin{array}{l}88.00^{\mathrm{b}} \pm \\
11.72\end{array}$ & $\begin{array}{l}81.75^{\mathrm{b}} \pm \\
10.58\end{array}$ & $\begin{array}{l}73.92^{\mathrm{b}} \pm \\
10.79\end{array}$ \\
\hline $\begin{array}{l}\text { Reference } \\
\text { (control) }\end{array}$ & $\begin{array}{l}85.58^{\mathrm{a}} \pm \\
7.27\end{array}$ & $\begin{array}{l}99.75^{\mathrm{a}} \pm \\
19.16\end{array}$ & $\begin{array}{l}116.25^{\mathrm{a}} \pm \\
9.90\end{array}$ & $\begin{array}{l}114.98^{\mathrm{a}} \pm \\
15.78\end{array}$ & $\begin{array}{l}111.42^{\mathrm{a}} \pm \\
15.32\end{array}$ & $\begin{array}{l}101.75^{\mathrm{a}} \pm \\
13.33\end{array}$ & $\begin{array}{l}85.03^{\mathrm{b}} \pm \\
8.88\end{array}$ \\
\hline Lettuce sauce & $\begin{array}{l}74.67^{\mathrm{a}} \pm \\
11.02\end{array}$ & $\begin{array}{l}87.83^{b} \pm \\
14.36\end{array}$ & $\begin{array}{l}87.83^{\mathrm{b}} \pm \\
13.78\end{array}$ & $\begin{array}{l}91.08^{\mathrm{b}} \pm \\
10.92\end{array}$ & $\begin{array}{l}86.58^{\mathrm{b}} \pm \\
14.42\end{array}$ & $\begin{array}{l}84.67^{b} \pm \\
13.01\end{array}$ & $\begin{array}{l}80.58^{\mathrm{b}} \pm \\
10.64\end{array}$ \\
\hline $\begin{array}{l}\text { Reference } \\
\text { (control) }\end{array}$ & $\begin{array}{l}83.75^{\mathrm{a}} \pm \\
17.02\end{array}$ & $\begin{array}{l}95.92^{\mathrm{a}} \pm \\
13.70\end{array}$ & $\begin{array}{l}115.50^{\mathrm{a}} \pm 17 . \\
91\end{array}$ & $\begin{array}{l}113.93^{\mathrm{a}} \pm \\
19.27\end{array}$ & $\begin{array}{l}98.92^{\mathrm{a}} \pm \\
29.34\end{array}$ & $\begin{array}{l}86.66^{\mathrm{a}} \pm \\
17.27\end{array}$ & $\begin{array}{l}83.42^{\mathrm{a}} \pm \\
16.01\end{array}$ \\
\hline
\end{tabular}

Mean values of with different superscript $(a, b, c)$ in the same row are significant at $p<0.05 . N=50$ 
Table 6: Post-prandial blood glucose increase/decrease of the vegetable sauce subjects (mg/dl).

\begin{tabular}{llllllll}
\hline $\begin{array}{l}\text { Vegetable } \\
\text { sauces }\end{array}$ & $\begin{array}{l}\mathbf{0} \\
\text { minute }\end{array}$ & $\begin{array}{l}\mathbf{1 5} \\
\text { minutes }\end{array}$ & $\begin{array}{l}\mathbf{3 0} \\
\text { minutes }\end{array}$ & $\begin{array}{l}\mathbf{4 5} \\
\text { minutes }\end{array}$ & $\begin{array}{l}\mathbf{6 0} \\
\text { minutes }\end{array}$ & $\begin{array}{l}\mathbf{9 0} \\
\text { minutes }\end{array}$ & $\begin{array}{l}\mathbf{1 2 0} \\
\text { minutes }\end{array}$ \\
\hline Okra sauce & 0 & 10 & -0.83 & 2.33 & -3.83 & -3.25 & -4.75 \\
$\begin{array}{l}\text { African } \\
\text { spinach sauce }\end{array}$ & 0 & 1.08 & 2.92 & 2.58 & 3.17 & -6.25 & -7.83 \\
Lettuce sauce & 0 & 13.16 & 0 & 3.25 & -4.5 & -1.91 & -4.09 \\
\hline
\end{tabular}

Table 7: Glycemic index and load of the vegetable sauces and white bread.

Vegetable sauces Glycemic index

Glycemic load

Okra sauce

17.02

0.75

African spinach

14.95

0.38

sauce

Lettuce sauce

36.76

3.80

White bread

93.25

54.91



Figure 1: Glycemic response of okra sauce. 


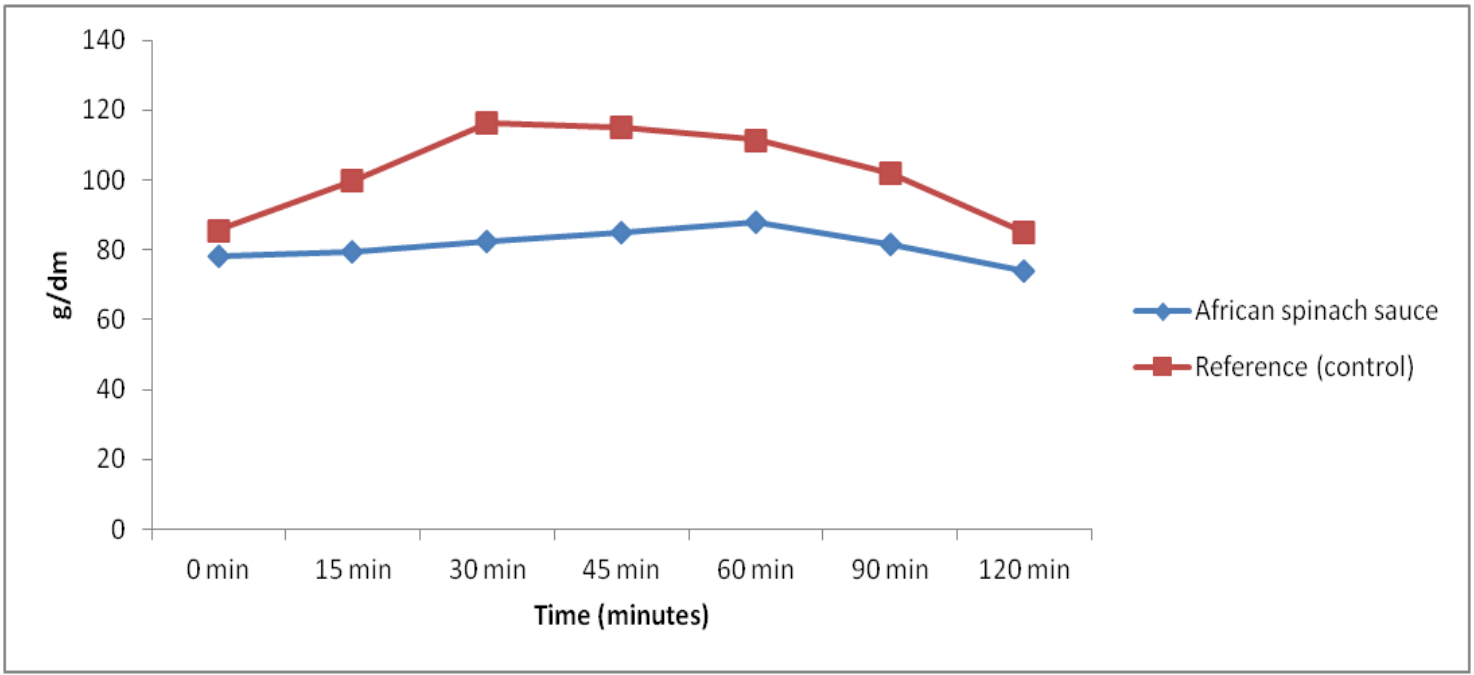

Figure 2: Glycemic response of African spinach sauce.

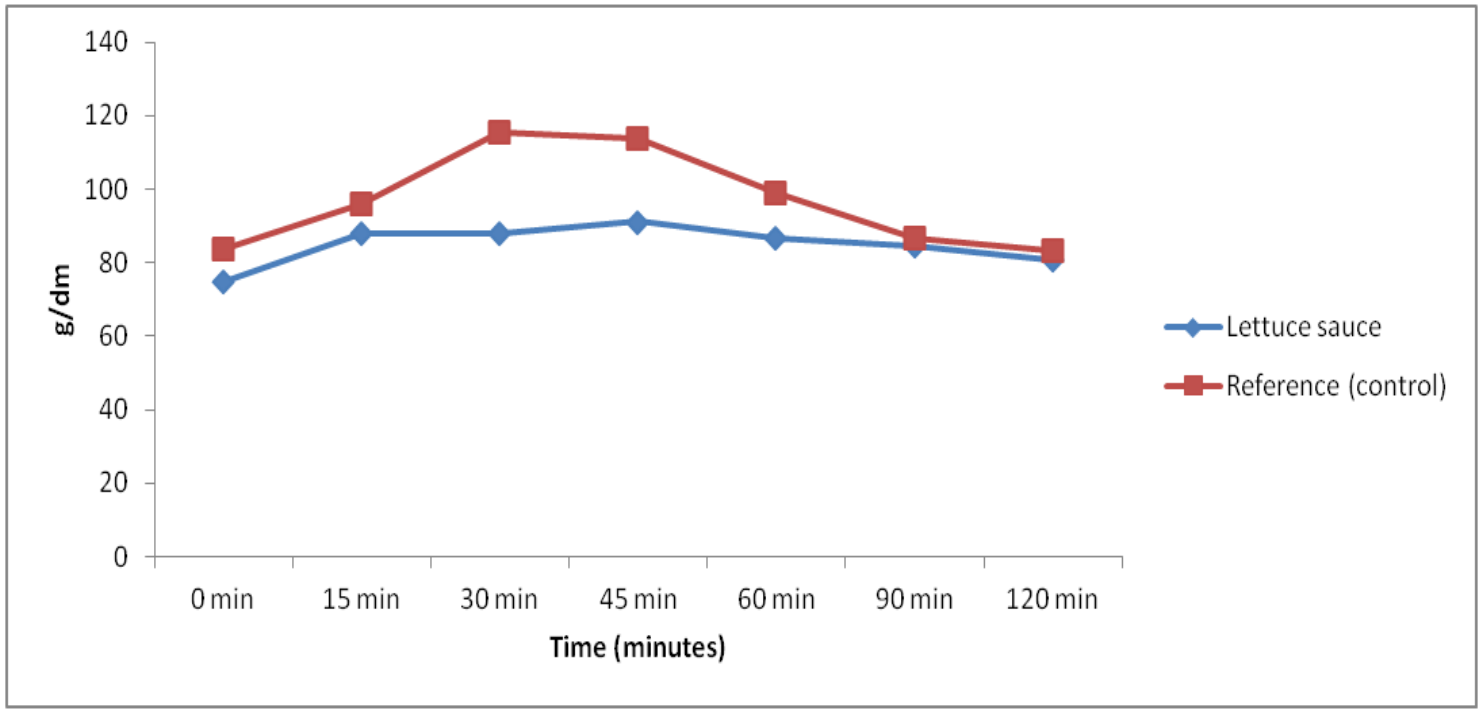

Figure 3: Glycemic response of lettuce sauce.



Figure 4: Glycemic response of okra, African Spinach and lettuce sauces. 


\section{DISCUSSION}

In the proximate analysis result of the present study, it was observed that the moisture contents of the vegetable sauces ranged from 64.10 to $64.62 \%$. This observation was similar with Ponka et al. [23], Kayode et al. [24], and Mawouma et al. [25] on traditional sauces consumed in Cameroon with moisture content ranging from 62.04 to $85.26 \mathrm{~g}, 63.11$ to 74.23 on soups consumed in SouthEast geopolitical zones of Nigeria, and 67.57 to $74.21 \mathrm{~g}$ on moringa oleifera sauces prepared in far North Region of Cameroon. The moisture content competed favorably with each other and was expected because it was analyzed fresh.

Protein adequacy is a public health issue because most individuals especially those among the low socio-economic class cannot always afford animal protein sources like meat and fish in sauce or soup preparation. In the present study, the recipe was formulated so as to accommodate people from the low socio-economic class. The use of ground crayfish was used excluding meat and fish. The vegetable sauce had more protein in the African spinach, okra, and lettuce sauces. The implication of the study was that if other animal sources of protein are added with grounded crayfish these will definitely increase the protein content. The study by Ponka et al. [23] used a similar recipe with the present study unlike Mawouma and Oguntona [26] that used assorted animal protein sources in their preparations. The study was higher than $11.38 \mathrm{~g}$ as reported by Ponka et al. [23] on the Baskodje (okra) sauce but lower than some sauces prepared with moringa oleifera [25] and Nigerian soups [24]. Protein energy malnutrition is on the increase in recent times, the preparation of vegetable sauces using the recipe in this study would help in providing some protein needs. The ash content of the vegetable sauces was significantly $(\mathrm{p}<0.05)$ higher in the lettuce sauce than other sauces. The study disagrees with other studies [26]. The reason for this could be explained by some inherent factors like species, variety, environment of the food crops, recipe, and cooking methods used [27].

Dietary fiber content of the vegetable sauces ranged from 2.25 to $3.26 \mathrm{~g}$ and was higher than 0.47 to 0.91 (ora soup) and 0.54 to 1.25 (egusi soup) as reported by Davidson et al. [26]. The dietary fiber content was lower than Nnadi and Keshiniro's study [28] on meat, okra soup with fermented cassava dough $(4.09 \mathrm{~g})$. They included other food sources like meat, dried fish, pumpkin leaves, and fermented cassava dough which contributed to the high dietary fiber content compared to the okra sauce $(3.26 \mathrm{~g})$ in the present study. Some individuals would like to modify this present recipe by adding meat and fish which will definitely increase the dietary fiber content. Also, sauces are eaten with fufu, rice, yam, plain maize pudding, and paste. This study was necessary in order to know the contribution of vegetable sauces excluding fufu or cereals on glycemic response. Dietary fat, especially saturated and trans-fat, is associated with an increased risk for several chronic diseases including type 2 diabetes mellitus and hypertension. The observation that fat contents of the vegetable sauces was higher in the lettuce sauce than in the other sauces but however it was quite low. Fat slows down the rate of digestion in the intestine which gives a low glycemic index when compared with similar food with little or without fat [29]. The aim of diabetes management is to reduce saturated fatty acids, trans-fatty acids, and cholesterol intake so as to limit the risk of cardiovascular diseases. The recipe in the present study was designed in a way that fat contribution from palm oil will be small. Energy content of the sauces was quite low compared to other literatures on dish preparation $[28,30]$. The vegetable sauce will accommodate little of the energy needs of adult diabetic patients. The low energy content can be appreciated by the low 
fat content of the sauces. The implication is that more vegetable sauce can be taken since it has a very low glycemic index.

The mean BMI indicates that all the subjects used for the study were healthy adults and was consistent with Amadi [31] who reported a mean BMI of $22.49 \pm 2.69 \mathrm{~kg} / \mathrm{m}^{2}$ among healthy undergraduate students on the determination of glycemic index of three cocoyam varieties unlike other previous studies $[32,33]$ where overweight subjects were used. Obesity or being overweight affect insulin sensitivity which inversely affects blood glucose level during metabolism thus affecting glycemic response [34]. Obesity or being overweight can also increase fat deposition in key insulin-sensitive tissues such as the liver [35] which causes hepatic insulin resistance through the mechanism that favors gluconeogenesis thereby decreasing glycogen synthesis and hindering insulin signals [36, 37].

Waist Hip Ratio (WHR) of the subjects shows that the subjects have normal WHR for females and do not have risk for cardiovascular and other diet related chronic diseases. The use of subjects with normal visceral fat accumulation should be encouraged because high levels of this fat predisposes subjects to glycemic and insulinemic disorder which gives a false result when determining glycemic index or response of meals. Visceral fat has lipolytic power that leads to insulin resistance [38]. It is closely related to WHR [39] and cardiovascular disease risk [40].

From the present study, the blood pressure and pulse rate of the subjects were normal [41]. This is because all the subjects in the study had normal BMI and WHR. Previous studies reported a significant association between being overweight and high blood pressure [42, 43]. Glycated hemoglobin $(\mathrm{HbA} 1 \mathrm{c})$ of all the subjects agrees with the recommended criteria of $4 \%-5.6 \%$ as normal [44] and this indicates that the subjects have a low risk for type 2 diabetes mellitus. The $\mathrm{HbA1c}$ of the subjects in the present study was also consistent with Asinobi et al. [30] on glycemic index of some traditional fortified staples. HbA1c is a form of hemoglobin that is used to identify plasma glucose increase and shows a clear picture of the red blood cells that have been glycated over a period of 120 days which is the life span of red blood cell [45]. In 2011, the WHO recommended $\mathrm{HbA} 1 \mathrm{c}$ for screening diabetes because it provides stringent quality assurance and standardization for diabetes mellitus studies. Also, as it does not require fasting, it has an analytical variability of less than 2\% and relatively stable over 2-3 months [46]. The African spinach sauce recorded the lowest crude fat content $(1.21 \%)$, whereas the lettuce sauce had the highest fat content (3.40\%). Studies proved that high fat content in food reduces the transit time thereby giving a low glycemic index [23, 29]. But the present study observed that the African spinach sauce had the lowest fat content $(1.21 \%$ ) compared to the other vegetable sauces. The reason could be attributed to factors like low amylase to high amylopectin content, nature of the monosaccharide components, fat, protein, dietary fiber, and anti-nutrients content of the foods that influence glycemic index and response of foods [47].

The study has established that okra, African spinach, and lettuce sauces have a low glycemic index, load, and response, and should be used in planning diets for diabetics. This will encourage diet diversity; though the same recipe was used but their nutrient contribution differed because of the vegetable used (Table 1). The study recommends that further studies should be carried out on these sauces with different tuber and cereal foods. Dietary fiber plays a role in controlling postprandial glycemic response because of its effects on gastric emptying and macronutrient absorption from the gut [28]. Dietary fiber helps to stabilize blood sugar by modulating sugar absorption from the intestinal tract [29]. 
Low glycemic index foods have some health benefits because of their metabolic effects, especially the ability of slowing down the rate at which glucose is absorbed from small intestine [48]. Vegetables generally have a low glycemic index value because of the presence of fiber. Glycemic load measures the degree of insulin demand and glycemic responses followed by a particular amount of food. It also reflects the quality and quantity of dietary carbohydrate consumed [49]. The African spinach sauce had the lowest glycemic index and glycemic load, followed by the okra and lettuce sauces. However, African spinach and okra sauces contained lower fat content, more protein, and higher dietary fiber than lettuce, and should be recommended to type 2 diabetes mellitus patients during meal planning because of its low glycemic index, load, and response potentials.

\section{CONCLUSION}

The glycemic response of indigenous vegetable sauces studied shows low GI and GL and moderate GR. Young healthy females in high-economic areas should use mainly foods from fresh vegetable sources for staving off risks of developing diabetes mellitus. Farmers should also go into the production of okra, African spinach, and lettuce so that they will be readily available. The study recommends that glycemic response of the vegetable sauces should be carried out on diabetic subjects and the effect of Homeostasis model assessment-estimated insulin resistance (HOMA-IR) should be evaluated.

List of abbreviations: non-communicable diseases (NCDs), cardiovascular disease (CVDs), type 1 diabetes mellitus (Type IDM),type 2 diabetes mellitus (Type 2DM), oral glucose tolerance test (OGTT), Federal Medical Center (FMC), body mass index (BMI), waist-hip ratio (WHR), Glycated hemoglobin $\left(\mathrm{HbA} 1_{\mathrm{c}}\right.$ ), Incremental Area Under the blood response curve for the test meal (IAUC), Incremental Area under the blood response curve for the standard reference meal (IAUCS), glycemic index (GI), glycemic response (GR), glycemic load (GL), Statistical Package for the Social Sciences (SPSS), Analysis of variance (ANOVA).

Competing interests: This study is part of my $\mathrm{PhD}$ thesis which has not been defended yet. The authors therefore declare no conflicting interests whatsoever.

Authors' contributions: Professor C.O Asinobi designed and supervised the study and corrected the manuscript; Mrs. Amadi Joy A.C designed the recipe, conducted the research, statistical analysis, and drafting and tying of the manuscript. Dr. Okechukwu-Ezike, N.C and Mr. Ihemeje, Austin conducted the nutrient analysis of the vegetable sauces while Dr. Aloy-Amadi, Oluchi helped in biochemical analysis and interpretation of the biochemical results.

Acknowledgements: We thank the Departmental board of Nutrition and Dietetics for their technical assistance and corrections.

\section{REFERENCES}

1. Onimawo I: Nigerian traditional food system and nutrition security. International scientific symposium on Biodiversity and sustainable diets united against hunger; 2010. 
2. Nnam NM, Onyechi JC, Madukwe EA: Nutrient and phytochemical composition of some leafy vegetables with medicinal significance. Nigerian Journal of Nutritional Sciences 2012, 33(2):15-19.

3. Kubmarawa D, Andenyang I, Magomya A: Proximate composition and amino acid profile of two non-conventional leafy vegetables (Hibiscus cannabinus and Haematostaphis bertei). African Journal of Food Science 2009, 3(9):233-236.

4. Sundarrayanan T, Kumia R, Sekar S: Antidiabetic activity of methanolic extract of Hibiscus cannabinusin streptozocin induced diabetic rats (Research Article). International Journal of Pharmacology and Biological Sciences 2011, 2(1):67-74.

5. Kearo IJ, Popkin BM, and Frison EA: Global nutrition dynamics: The world is Shifting rapidly toward a diet linked with non-communicable diseases. American Journal of clinical Nutrition 2010, 84:289-298.

6. Gaikwad SB, Mohan GK, Rani MS: Phytochemicals for diabetes management. Pharmaceutical Crops 2014, 5(Suppl 1:M2):11-28.

7. Ayogu R, Edeh R, Madukwe E, Ene-Obong H: Commonly Consumed Foods: Nutritional Quality and Contributions to Recommended Nutrient Intakes of Schoolchildren in Rural Southeastern Nigeria. Food and Nutrition Bulletin 2017, 38(1):65-77.

8. Uraku AJ, Ajah PM, Okaka ANC, Ibiam UA, Onu PN: Effects of crude extract of Abelmoschus esculentus on Albumin and total bilirubin of diabetic albino rats. International Journal of Science and Nature 2010, 1(1):38-41.

9. Radulian G, Rusu E, Drragomir A, Posea M: Metabolic effects of low glycemic index diets. Nutrition Journal 2009, 8:5.

10. Balasubramanian T, Karthikeyan M: Therapeutic Effect of Amaranthus hybridus on Diabetic Nephropathy. Journal of development drugs 2016, 5(1):147-151

11. Mukesh R, Namita P: Medicinal Plants with Antidiabetic Potential - A Review. AmericanEurasian Journal of Agriculture and Environmental Science 2013, 13(1):81-94.

12. Onwuka GI: Food Analysis and Instrumentation: Theory and Practice. Naphtali Print, Lagos, Nigeria, 2005, 81-90.

13. Association of Official Analytical Chemists (AOAC): Official Methods of Analysis. 17th edition. Association of Official Analytical Chemists: Washington D.C., 2010.

14. McCleary BV, Sloane N, Draga A, Lazewska I: Measurement of total dietary fibre using AOAC method 2009.01 (AACA international approved method 32-45.01): Evaluation and Update. Cereals Chemistry 2013, 9:396-414.

15. FAO: Calculation of the Energy Content of Foods - Energy Conversion Factors. FAO Food and Nutrition Paper 2003, 77:18-56.

16. WHO Expert Consultation: Appropriate body-mass index for Asian populations and its implications for policy and intervention strategies. Lancet 2004, 363(9403):157-63.

17. William DC, Huff GF: Glucose oxidase chemiluminescence measurement of glucose in urine with the hexokinase method. Clinical Chemistry 1976, 22(3):372- 4.

18. Ngwu EK, Nwabunze AM: Prevalence and presentation of diabetes mellitus among patients attending the University of Nigeria, Nsukka campus Medical Centre. Nigerian Journal of Nutritional Sciences 2008, 29(1):216-230.

19. Brouns F, Bjorock I, Frayn KN, Gibbs AL, Lang V, Slama G, Wolever TM: Glycemic index methodology. Nutrition Research Review 2005, 18(1):145-71. 
20. FAO/WHO: Carbohydrates in Human Nutrition. Report of a joint FAO/WHO experts consultation, Rome, 14-18 April 1997. FAO food and nutrition paper 1997, 66.

21. Hanhineva K, Torronen R, Bondia-Pons I, Pekkinen J, Kolehmainen M, Mykkanen H, Poutanen K: Impact of dietary polyphenols on carbohydrate metabolism. International Journal of Molecular Science 2010, 11(4):1365-1402.

22. Das SK, Gilhooly CH, Golden JK, Pittas AG, Fuss PJ, Cheatham RA, Tyler S, et al.: Longterm effects of 2 energy-restricted diets differing in glycemic load on dietary adherence, body composition, and metabolism in CALERIE: a 1-y randomized controlled trial. American Journal of Clinical Nutrition 2007, 85(4):1023-1030.

23. Ponka R, Fokou E, Kansci G, Beaucher E, Piot M, Leonil J, Gaucheron F: Recipes, proximate and mineral composition of some traditional sauces consumed in the far North Region of Cameroon. International Food Research Journal 2014, 21(4):1589-1596.

24. Kayode OF, Ozumba AU, Ojeniyi S, Adetuyi DO, Erukainure O: Micronutrient content of selected indigenous soups in Nigeria. Pakistan Journal of Nutrition 2010, 9(10):962965.

25. Mawouma S, Ponka R, Mbofung CM: Composition of 13 different traditional sauces prepared from moringa olifera leaves in the far North Region of Cameroon. International Journal of Innovative and Applied Studies 2014, 7(3):1129-1136.

26. Davidson GI, Ene-Obong HN, Chinma CE: Variations in Nutrients composition of most commonly consumed cassava (Manihot esculenta) mixed dishes in South-Eastern Nigeria. Journal of Food Quality 2017, 1-8.

27. Eleazu CO: The Concept of low glycemic index and glycemic load foods as panacea for type 2 diabetes mellitus; prospects, challenges and solutions. African Health Science 2016, 16(2):468-479.

28. Nnadi IM, Keshinro OO: The effect of glycaemic response of the three commonly consumed meals on postprandial plasma glucose in type 2 diabetics at the University Teaching Hospital, Enugu. South African Journal of Clinical Nutrition 2016, 29(2):90-94.

29. Kouame CA, Kouassi NK, Coulibaly A, N'dri DY, Tiahou GG, Adrien L, Amani GN: Glycemic index and glycemic load of selected staples based on rice, yam, and cassava commonly consumed in Cote d'Ivoire. Food and Nutrition Sciences 2014, 5:308-315.

30. Asinobi C, Uzoagba H, Mba-Anyadioha A, Nnodim J: Glycemic index of some traditional fortified staple meals on the postprandial glucose response of Nigerian undergraduate students: an open-label study. Functional foods in Health and Disease 2016, 6(7):414-424.

31. Amadi JAC: Glycemic Index of three Cocoyam varieties consumed in Imo State Nigeria. Journal of Dietitians Association of Nigeria 2017, (8):96-103.

32. Queiroz KC, Silva IN, Alfenas G: Influence of glycemic index and glycemic load of diet in glycemic control of diabetic children and teenagers. Nutrition Hospital 2012, 27(2):110.

33. AlGeffari MA, Almogbel ES, Alhomaidan HT, El-Mergawi R, Barrimah IA: Glycemic indices, glycemic load and glycemic response for seventeen varieties of dates grown in Saudi Arabia. Annals of Saudi Medicine 2016, 36(6):397-403.

34. Pereira MA, Jacobs DR Jr, Pins JJ, Raatz SK, Gross MD, Slavin JL, Seaquist ER: Effect of whole grains on insulin sensitivity in overweight hyperinsulinenic adults. American Journal of Clinical Nutrition 2002, 75:848-855. 
35. Janssen I, Katzmarzyk PT, Ross R: Body mass index, waist circumference, and health risk: evidence in support of current National Institutes of Health guidelines. Archives of Internal Medicine 2002, 162:2074-2079.

36. Mathieu P, Poirier P, Pibarot P, Lemieux I, Despres JP: Visceral obesity: the link among inflammation, hypertension, and cardiovascular disease. Hypertension 2009, 53:577-584.

37. Dulskiene V, Kuciene R, Medzioniene J, Benetis R: Association between obesity and high blood pressure among Lithuanian adolescents: a cross-sectional study. Italian Journal of Pediatrics 2014, 40:102.

38. Zhang CX, Shi JD, Huang HY, Feng LM, Ma J: Nutritional status and its relationship with blood pressure among children and adolescents in South China. European Journal of Pediatrics 2012, 17(1):1073-107.

39. Eckel RH, Kahn SE, Ferrannini E, Goldfine AB, Nathan DM, Schwartz MW, Smith RJ, et al.: Obesity and type 2 diabetes: what can be unified and what needs to be individualized? Journal of Clinical Endocrinology and metabolism 2011, 96(6):1654-63.

40. Hardy OT, Czech MP, Corvera S: What causes the insulin resistance underlying obesity? Current Opinion on Endocrinology, Diabetes and Obesity 2012, 96(6):1654-63

41. Gao D, Nong S, Huang X, Lu Y, Zhao H, Lin Y, Man Y, et al.: The effects of palmitate on hepatic insulin resistance are mediated by NADPH Oxidase 3-derived reactive oxygen species through JNK and p38MAPK pathways. Journal of Biology and Chemistry 2010, 285:29965-29973.

42. Samuel VT, Shulman GI: Mechanism for insulin resistance: common threads and missing links. Cell 2012, 148(5):852-87.

43. Mohammadifard N, Nazem M, Sarrafzadegan N, Nouri F, Sajjadi F, Maghroun M, Alikhasi H: Body mass index, waist-circumference and cardiovascular disease risk factor in Iranain Adults: Isfahan healthy heart Program. Journal of Health and Population Nutrition 2013, 31(3):388-397.

44. American Diabetes Association: Classification and Diagnosis of Diabetes: Standards of Medical Care in Diabetes-2018. Diabetes Care 2018, 41(Suppl 1): S13-S27.

45. Nathan DM, Kuenen J, Borg R, Zheng H, Schoenfeld D, Heine RJ: A1c-Derived Average Glucose Study Group: Translating the A1C assay into estimated average glucose values. Diabetes Care 2008, 31(8):1473-1478.

46. Kumar PR, Bhansali A, Ravikiran M, Bhansali S, Dutta P, Thakur JS, Sachdeva N, et al.: Utility of glycated hemoglobin in diagnosing Type 2 diabetes mellitus: a communitybased study. Journal Clinical and Endocrinology Metabolism 2010, 95:2832-5.

47. Hodge AM, English DR, O'Dea K, Giles GG: Glycemic index and dietary fiber and the risk of type 2 diabetes. Diabetes care 2004, 27(11):2701-2706.

48. Kendall CWC, Augustin LSA, Emam A, Josse AR, Saxena N, Jenkins DJA: The glycemic index: methodology and use. Nestle Nutr Workshop Ser Clinical and Programme 2006, 11:43-56.

49. Augustin LS, Kendall CW, Jenkins DJ, Willet WC, Astrup A, Barclay AW, Bjorck I, et al.: Glycemic index, glycemic load and glycemic response: An International Scientific Consensus summit from International Carbohydrate Quality Consortium (ICQC). Nutrition, Metabolism and Cardiovascular Diseases 2015, 25(9):795-815. 